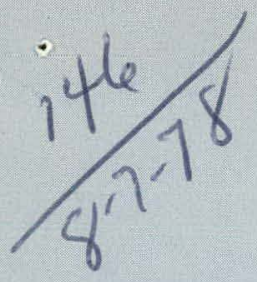

\title{
AUTOMATED MICROPROCESSOR-CONTROLLED ATOMIC ABSORPTION ANALYSIS OF NATURAL WATER FOR ARSENIC AND SELENIUM
}

\author{
R. W. Morrow \\ T. L. Futrell \\ T. T. Adams
}

Adapted from a paper that was presented at the 20th Annual Conference on Analytical Chemistry in Energy and Environmental Technology, Gatlinburg, Tennessee, October 12 14, 1976; to the Third Annual Meeting of the Federation of Analytical Chemistry and Spectroscopy Societies, Philadelphia, Pennsylvania, November $15-19,1976$; and included in a book entitled: Environmental Analysis, Edited by Galen W. Ewing, Academic Press (1977). 


\section{DISCLAIMER}

This report was prepared as an account of work sponsored by an agency of the United States Government. Neither the United States Government nor any agency Thereof, nor any of their employees, makes any warranty, express or implied, or assumes any legal liability or responsibility for the accuracy, completeness, or usefulness of any information, apparatus, product, or process disclosed, or represents that its use would not infringe privately owned rights. Reference herein to any specific commercial product, process, or service by trade name, trademark, manufacturer, or otherwise does not necessarily constitute or imply its endorsement, recommendation, or favoring by the United States Government or any agency thereof. The views and opinions of authors expressed herein do not necessarily state or reflect those of the United States Government or any agency thereof. 


\section{DISCLAIMER}

Portions of this document may be illegible in electronic image products. Images are produced from the best available original document. 
Reference to a company or product name does not imply approval or recommendation of the product by Union Carbide Corporation or the Department of Energy to the exclusion of others that may meet specifications.

Printed in the United States of America. Available from National Technical Information Service

U.S. Department of Commerce

5285 Port Royal Road, Springfield, Virginia 22161

Price: Printed Copy $\$ 4.00 ;$ Microfiche $\$ 3.00$

This report was prepared as an account of work sponsored by an agency of the United States Government. Neither the United States Government nor any agency thereof, nor any of their employees, nor any of their contractors, subcontractors, or their employees, makes any warranty, express or implied, nor assumes any legal liability or responsibility for any third party's use or the results of such use of any information, apparatus, product or process disclosed in this report, nor represents that its use by such third party would not infringe privately owned rights. 


\title{
AUTOMATED MICROPROCESSOR-CONTROLLED ATOMIC ABSORPTION ANALYSIS OF NATURAL WATER FOR ARSENIC AND SELENIUM
}

\author{
R. W. Morrow \\ T. L. Futrell \\ T. T. Adams \\ Y-12 Plant Laboratory \\ Product Certification Division
}

\begin{abstract}
Adapted from a paper that was presented at the 20th Annual Conference on Analytical Chemistry in Energy and Environmental Technology, Gatlinburg, Tennessee, October $12-14$ 1976; to the Third Annual Meeting of the Federation of Analytical Chemistry and Spectroscopy Societies, Philadelphia, Pennsylvania, November $15-19,1976$; and included in a book entitled: Environmental Analysis, Edited by Galen W. Ewing, Academic Press (1977).
\end{abstract}

\section{Oak Ridge Y-12 Plant}

P. O. Box Y, Oak Ridge, Tennessee 37830

Prepared for the Department of Energy Under US Gnvẹrnment Contract W-7405-eng-26 


\begin{abstract}
An automated, dual-channel atomic absorption spectrophotometer for the simultaneous determination of arsenic and selenium in natural water is now in operation. The instrument will analyze samples at a rate of 37 per hour, and a quantitative determination of arsenic and selenium to $0.2 \mu \mathrm{g} / \mathrm{l}(\mathrm{ppb})$ can be achieved.
\end{abstract}




\section{CONTENTS}

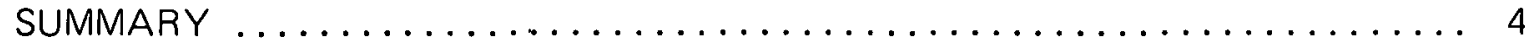

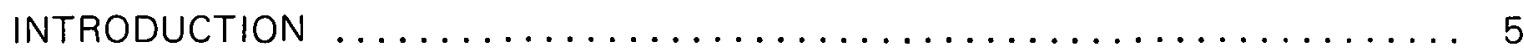

ANALYSIS OF NATURAL WATER FOR ARSENIC AND SELENIUM $\ldots \ldots \ldots \ldots$

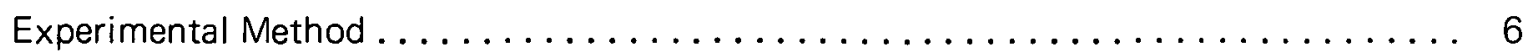

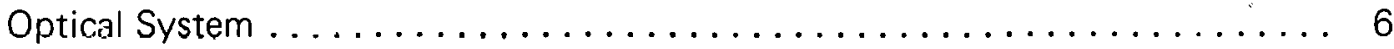

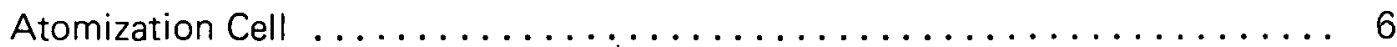

Sample-Entry System . . . . . . . . . . . . . . . . . . . . . . . 6

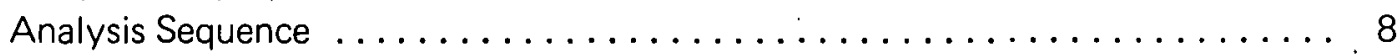

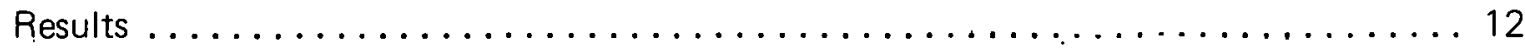

Instrumental Conditions . . . . . . . . . . . . . . . . . . . . 12

Analysis of the Standard Solutions . . . . . . . . . . . . . . . . 13

Analysis of the Natural-Water Samples . . . . . . . . . . . . . . . . 14

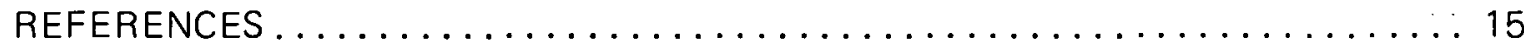




\section{SUMMARY}

An automated, dual-channel atomic absorption spectrophotometer for the simultaneous determination of arsenic and selenium in natural water is now in operation. The instrument was constructed from commercially available optical components, spectral sources, and a sample changer. Automation was achieved by using an in-house-fabricated and programmed microprocessor. The instrument will analyze samples at a rate of 37 per hour, and a quantitative determination of arsenic and selenium to $0.2 \mu \mathrm{g} / \mathrm{l}(\mathrm{ppb})$ can be achieved. Arsenic can be determined with a precision of $19 \%$ at $1 \mu \mathrm{g} / \mathrm{l}$ and $6 \%$ at $10 \mu \mathrm{g} / \mathrm{l}$, while selenium can be determined with a precision of $17 \%$ at $1 \mu \mathrm{g} / \mathrm{l}$ and $4 \%$ at $10 \mu \mathrm{g} / \mathrm{l}$. 


\section{INTRODUCTION}

A hydrogeochemical-stream and ground-water survey is being conducted by the Union Carbide Corporation's Nuclear Division as part of the National Uranium Resource Evaluation (NURE) project. A portion of this survey will include a water analysis for uranium and 23 additional elements. Uranium is determined by fluorescence and mass spectrometry; most of the remaining elements are determined by emission spectroscopy. However, two of these elements, arsenic and selenium, cannot be determined by emission spectroscopy due to the lack of sensitivity.

Arsenic and selenium occur in natural water at concentrations that range from less than $0.2 \mu \mathrm{g} / \mathrm{l}(\mathrm{ppb})$ to greater than $50 \mu \mathrm{g} / \mathrm{l}(\mathrm{ppb})$. These elements are of special significance to the NURE program because they are considered "pathfinder" elements for uranium deposits, and samples must be analyzed with sufficient sensitivity to measure at the natural concentration level. The only method possessing this sensitivity available to the Oak Ridye Y-12 Plant Laboratory ${ }^{(a)}$ was hydride generation/flameless atomic absorption spectroscopy.

Atomic absorption procedures for determining arsenic and selenium in waters by reduction to the corresponding covalent hydrides with sodium borohydride $\left(\mathrm{NaBH}_{4}\right)$ and sparging into an argon-entrained air flame have been described by Fernandez, ${ }^{1}$ King and Morrow, ${ }^{2}$ and others. 3,4 However, these procedures do not have a sufficient cost-effective sample throughput rate to analyze the 100,000 water samples expected to be collected by the NURE project. Various automated and semiautomated systems for determining arsenic and selenium by atomic absorption spectroscopy have also been described. 5 - 7 Again, these systems are either too complex, lack sufficient sample-throughput capacity, or do not have suitable sensitivity to meet the expected project needs.

A completely automated-microprocessor-controlled, dual-channel, atomic-absorption spectrophotometer that satisfies the stated analytical and economic needs has been assembled. The instrument utilizes commercial optics, spectral sources, and a sample changer, plus a custom-built microprocessor controller. Arsenic and selenium are determined simultaneously to concentrations less than $0.2 \mu \mathrm{g} / \mathrm{l}(\mathrm{ppb})$, with each sample being analyzed every 97 seconds ( $1.5 \mathrm{~min})$.

(a) The Oak Ridge Y-12 Plant is operated by the Union Carbide Corporation's Nuclear Division for the Department of Energy. 


\section{ANALYSIS OF NATURAL WATER FOR ARSENIC AND SELENIUM}

\section{EXPERIMENTAL METHOD}

\section{Optical System}

A photograph of the automated, dual-channel, atomic-absorption spectrophotometer is presented in Figure 1. The instrument consists of a $0.5-\mathrm{m}$ monochromator, electrodeless discharge lamps for arsenic and selenium, a rotating-blade chopper mirror, a heated quartz atomizer, a sample changer, a recorder, readout electronics, the microprocessor control unit, and tubing pumps for the sample and reagents. Commercially available components were used wherever possible; for example, a Jarrell-Ash 0.5-m monochromator and Perkin-Elmer electrodeless discharge lamps for arsenic and selenium. A rotating-blade chopper mirror serves to transmit the beam from the arsenic lamp and then to reflect the selenium lamp beam through the atomization cell. The chopper mirror rotates at $120 \mathrm{rpm}$ and has a chopping frequency of $16 \mathrm{~Hz}$. The unit was fabricated fróm a commercial chopper device and housing; the blade was fabricated in $Y-12$ from $4.76-\mathrm{mm}(3 / 16-i n)$ aluminum, with the forward surface machined and polished to a $0.13-\mu \mathrm{m}(5-\mu \mathrm{in})$ tolerance. This machined surface has greater than $80 \%$ reflectivity for the selenium $196.0-\mathrm{nm}$ spectral line.

A $300-\mu \mathrm{m}$ entrance slit and a fabricated dual-exit slit were used on the monochromator. Two slits, $0.5 \mathrm{~mm}$ wide, were cut $0.8 \mathrm{~mm}$ apart. With a monochromator dispersion of 3.2 $\mathrm{nm} / \mathrm{mm}$, the 193.5- $\mathrm{nm}$ arsenic line will pass one slit, followed by the 196.0-nm selenium line passing the other slit. Both of these spectral lines are then detected sequentially by the photomultiplier tube.

\section{Atomization Cell}

A $1.5-\mathrm{cm}-\mathrm{OD}$ by $17-\mathrm{cm}$-long quartz tube with open ends was used to fabricate the cell for atomization of the collected arsenic and selenium hydrides. The tube was wrapped with sufficient Nichrome ribbon to reach a cell temperature of $800^{\circ} \mathrm{C}$ by resistance heating. $A$ one-inch-thick section of magnesium oxide insulation (similar to that used for steam pipes) was used to achieve a uniform temperature distribution. Power to the heater ribbon is supplied by a variable transformer, and the temperature is regulated, using a furnace controller. A mount on the optical rail allows precise vertical and horizontal positioning of the atomization cell relative to the spectral beams.

\section{Sample-Entry System}

The hydride-generation reactor, seen in Figure 1, was fabricated from a 250-ml graduated cylinder and has an internal volume of approximately $150 \mathrm{ml}$. A $17-\mathrm{cm}$-long cylindrical balloon is attached to collect the generated hydrides and excess hydrogen. This balloon has two open ends-one end is attached to the reactor and the other end is attached to the argon line-and is used to purge the cell. With this arrangement, the balloon is rapidly purged, yielding sharp reproducible absorption peaks. 


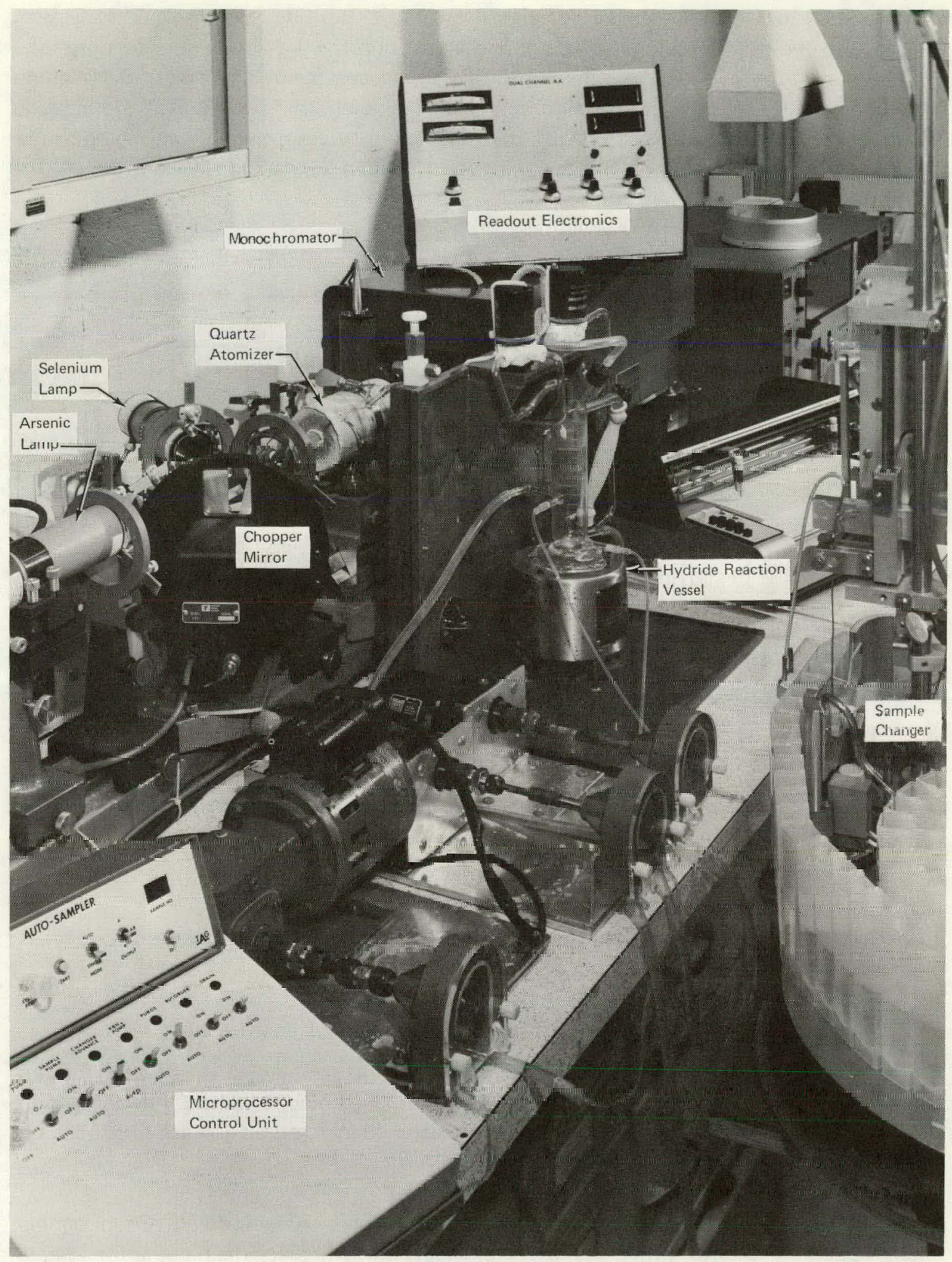

Figure 1. AUTOMATED ATOMIC ABSORPTION SPECTROPHOTOMETER. 
Figure 2 is a block diagram of the complete instrument, showing the sample entry system. The two solenoid valves, shown above the reactor, control the argon flow to purge the balloon and reactor, or to bypass the reactor. By this arrangement, a constant flow of argon is maintained through the atomization cell to aid in establishing a constant atomization temperature. The third solenoid valve (Figure 2 ) is used to drain the reactor contents after purging. The argon-purge solenoids and drain solenoid are under control of the microprocessor.

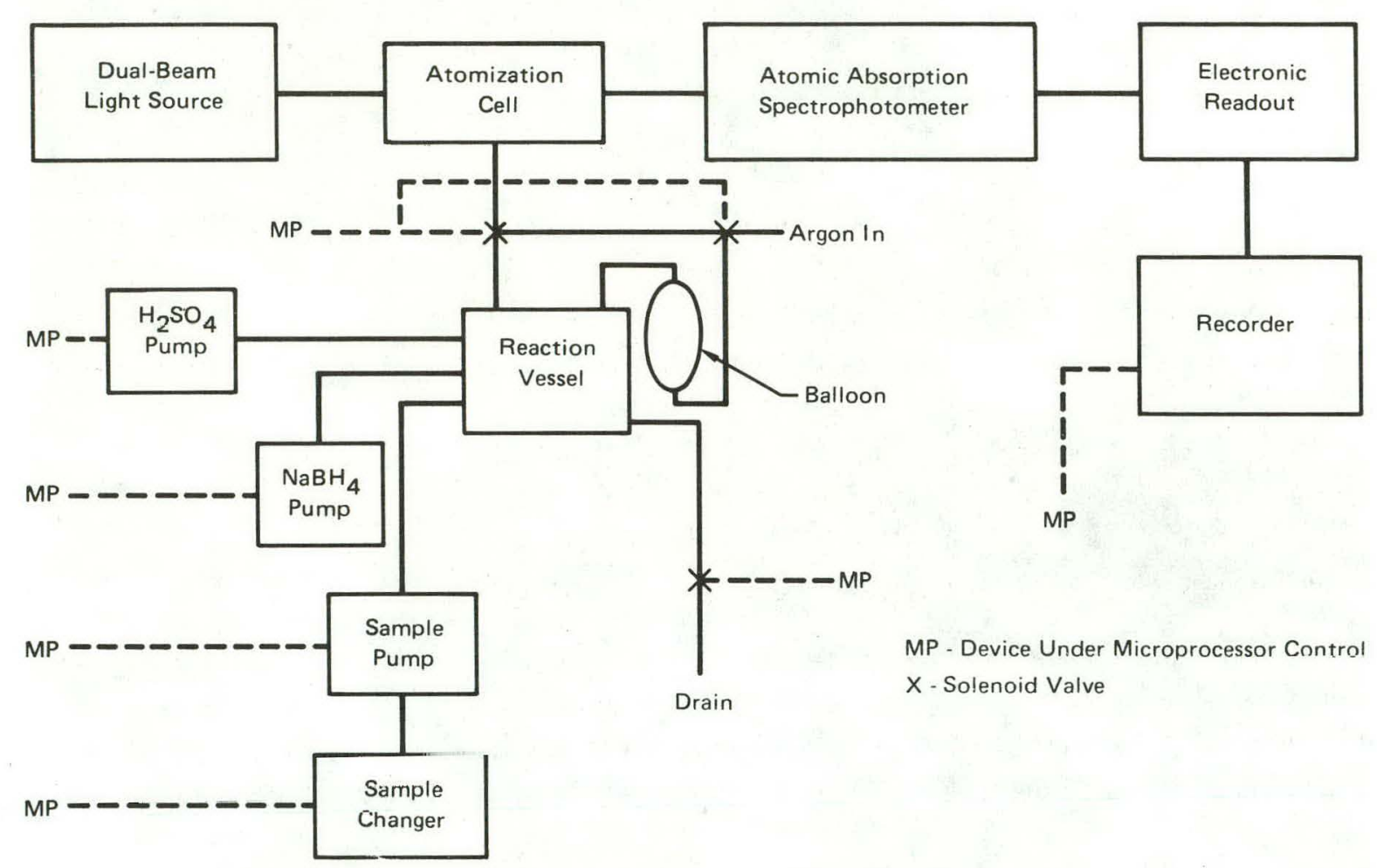

Figure 2. PRINCIPAL COMPONENTS OF THE AUTOMATED ATOMIC ABSORPTION SPECTROPHOTOMETER.

The three high-speed pumps in Figure 2 are used to pump sample and rinse water, sodium borohydride solution, and sulfuric acid solution through tubing to the hydride-generation reactor. These pumps deliver solution at a rate greater than $1 \mathrm{ml} / \mathrm{sec}$ and are controlled by the microprocessor.

The sample changer is a Gilson Model T035 and will accommodate up to $20035-\mathrm{ml}$ sample tubes snapped together to form a chain. The pipetting unit will place the pipet in the sample vial and then in the rinse vial containing demineralized water. The time interval the pipet remains in the vial and, thus, the volume of sample and rinse pumped to the reactor, are controlled by the microprocessor. 


\section{Analysis Sequence}

The sequence of events controlled by the microprocessor during the analysis of a sample is illustrated in Figure 3. The bars show the time the sample, sodium borohydride solution and

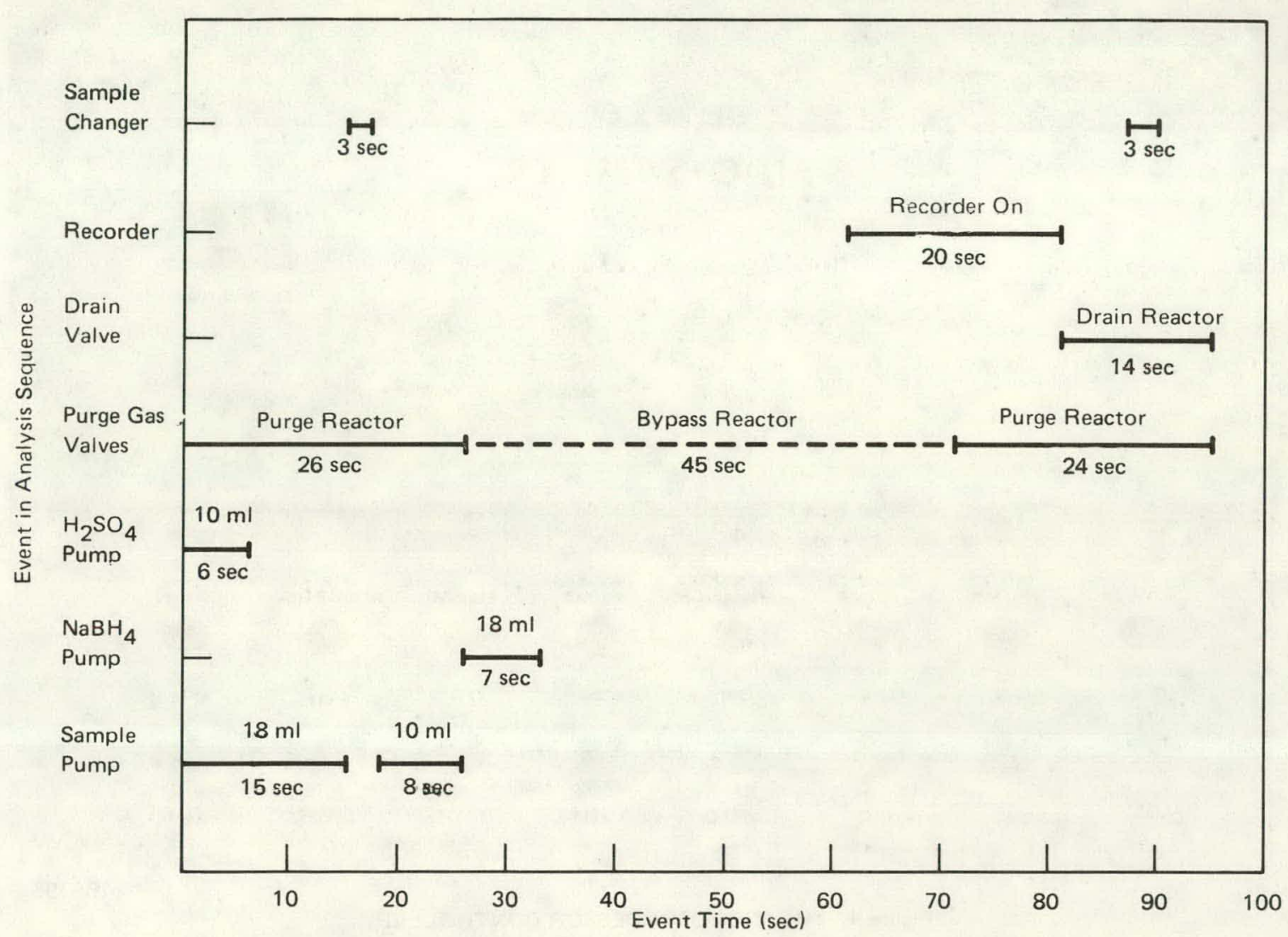

Figure 3. EVENTS CONTROLLED BY THE MICROPROCESSOR.

sulfuric acid pumps are on, and the volume of solutions pumped. The reactor is seen to be purged during the 26 seconds required for the addition of $18 \mathrm{ml}$ of sample and $10 \mathrm{ml}$ of $15 \%$ sulfuric acid, and for the sampling pipet to change to the rinse vial and pump $10 \mathrm{ml}$ of rinse water. Purging the reactor during these events assures that all residual air is removed, thus eliminating this source of nonatomic absorption. Switching of the solenoid valves isolates the reactor for 45 seconds, and the argon passes directly to the quartz atomization cell. For the first 7 seconds of this time interval, $18 \mathrm{ml}$ of $0.10 \%$ sodium borohydride are added to the reactor. The system is then quiescent for the remaining 38 seconds to allow reduction of the arsenic and selenium to the volatile hydrides. The recorder is activated for 10 seconds before the solenoid valves switch to purge the hydrides and excess hydrogen from the balloon and reactor. An additional 10 seconds of recorder time are allowed to assure display of the absorption peak tailing edge and a stable baseline. At this point, the solenoid drain valve opens to expel the spent solution from the reactor. The system resets to time zero, and analysis of the next sample begins. The entire analysis sequence requires 97 seconds, yieldiny an analysis rate of 37 samples per hour. 
A view of the microcomputer system used to automate the analysis is given in Figure 4 . The system was constructed in an enclosure comparable to the size of a desk calculator. On the lower panel are switches which give the operator independent control of each of the pumps

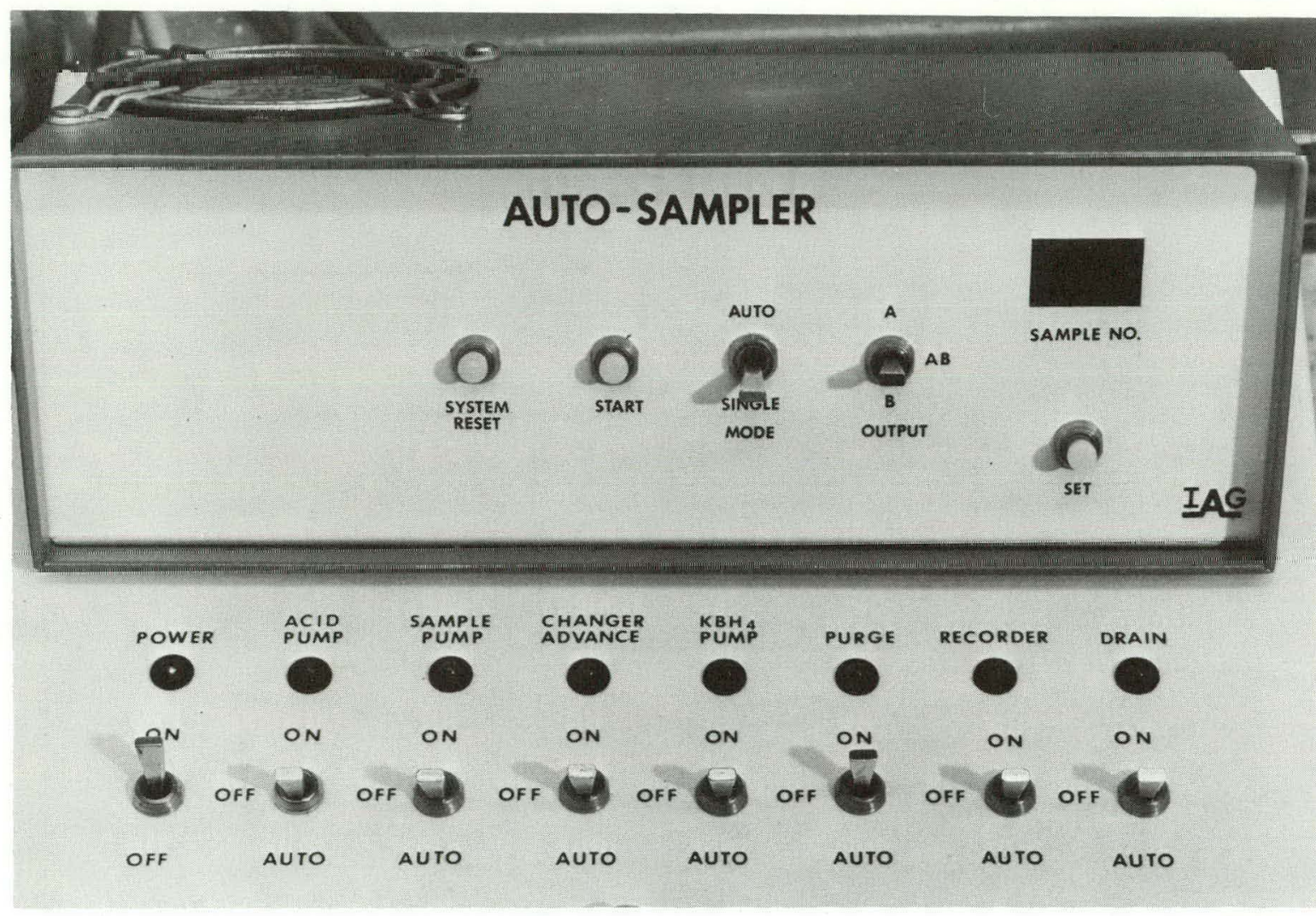

Figure 4. THE MICROPROCESSOR CONTROLLER.

169396

and valves, the sample changer, and the recorder. Manual or automatic operation may be selected, or any of these devices may be disabled. On the upper panel are switches which reset and start the system operation, which control the output of data to tape, and which enable the operator to set the two-digit sample counter to any desired number. An additional small enclosure is used to house the optically isolated, solid-state relays which are controlled by the microcomputer.

Figure 5 is a block diagram of the microcomputer electronics. The system consists of four circuit boards 10.8 by $17.8 \mathrm{~cm}$ ( 4.25 by 7 in) in size which are components of the JOLT system produced by Microcomputer Associates, Incorporated.

The microprocessor unit (MPU) board on the left contains the microprocessor, 512 bytes of random access memory, a programmable timer, and three 8-bit parallel interface ports. The MCS 6502 microprocessor is used to control the system. The microprocessor is capable of addressing $64 \mathrm{~K}$ bytes of memory or input/output devices, and has an 8-bit bidirectional data bus. An internal clock, two levels of vectored interrupt, 13 addressing modes, and 137 instructions are provided. The MCS 6530 is a combination device which contains a 
programmable interval timer, a monitor program in $1 \mathrm{~K}$ of read-only memory, and an 8-bit parallel input/output port. As shown in the drawing, this port is buffered and used to activate the solid-state relays which control the sample-entry sequence. Also contained on the board is an MC 6820 peripheral interface adapter, which contains two additional 8-bit input/output ports. One of these ports communicates with the front-panel control switches and sample counter; the other outputs data to an incremental cassette tape deck.

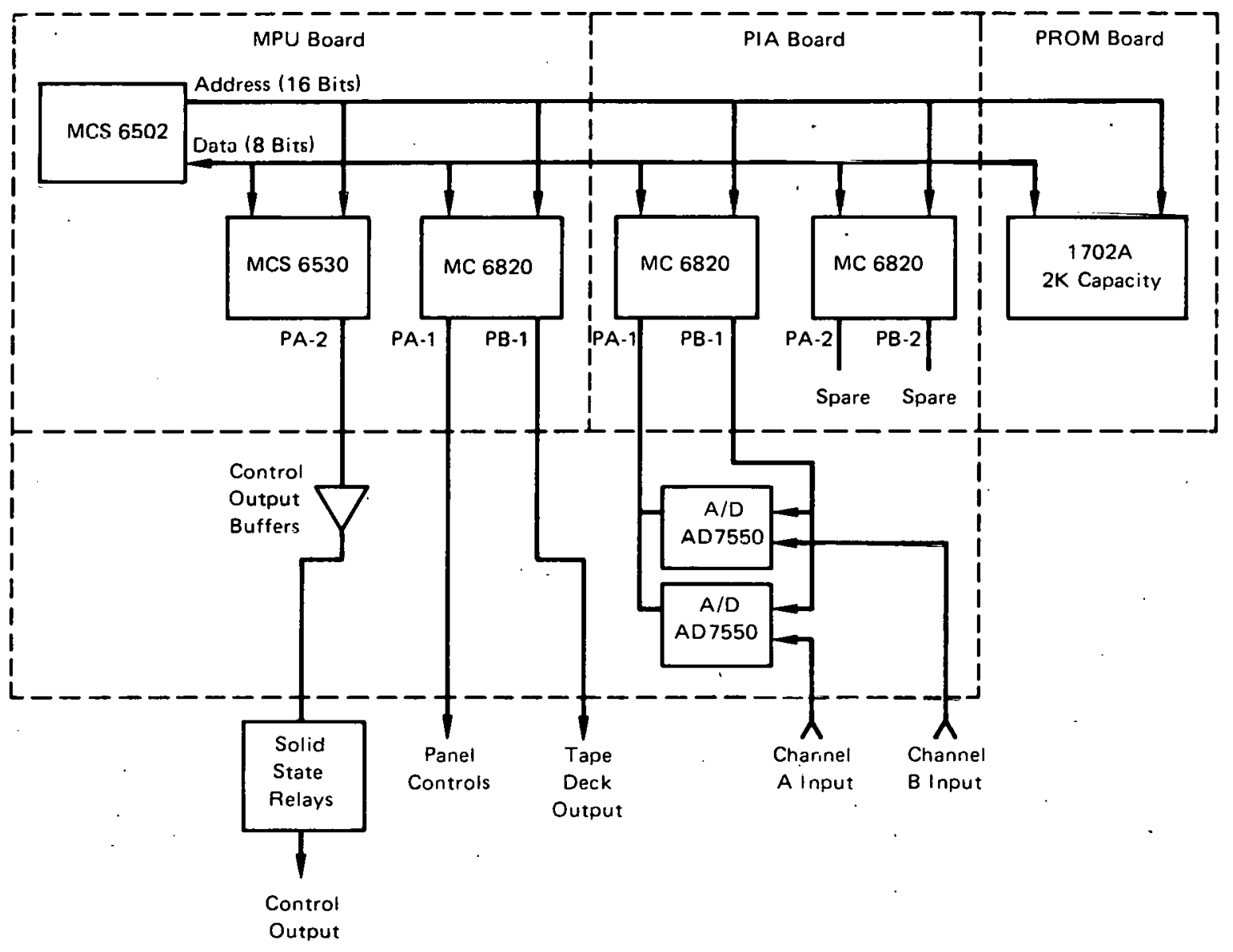

Figure 5. MIĆROPROCESSOR ELEC"THONICS.

The peripheral interface adapter (PIA) board in the middle provides two additional MC 6820 peripheral interface adapters having a total of four 8-bit parallel ports. One port is used to input data from two byte-oriented, 13-bit, analog-to-digital (A/D) converters and one controls the converters; the two remaining poits are unused.

The board on the extreme right is used for storing the system program in programmable read-only memory. The board can store up to $2 \mathrm{~K}$ bytes of programming iri eight $1702 \mathrm{~A}$ proms.

The buffers for the control output and the two A/D converters were fabricated on a universal breadboard card which is also a part of the JOLT system, and which has the same form factor as the other cards. 
Programming the microprocessor was a relatively easy task. The available interface adapters not only provide flexible interfacing, but also greatly simplify the input/output program routines. A key element in the microcomputer system is the programmable interval timer, which allows a real-time clock with a one-second time base to be easily programmed by use of an interrupt-service routine. In executing the control sequence, the system simply idles until the appropriate time interval has been reached, outputs the corresponding control command to the relays, and returns to the idle condition. At the end of the control sequence, a panel-mounted switch is monitored to determine if the operator desires continued analysis of additional samples. While data acquisition and output hardware are presently on the system, the programming for these functions has not yet been performed.

\section{RESULTS}

\section{Instrumental Conditions}

Absorbance of both arsenic and selenium was found to be dependent upon the atomization cell temperature. An optimum temperature of $800^{\circ} \mathrm{C}$ was found, as measured with a thermocouple inserted down the quartz tube. This temperature is slightly less than required for combustion of the hydrogen gas as it emerges from the ends of the quartz atomization tube. Absorbance was found to be nearly independent of the argon purge gas flow at a constant cell temperature. A convenient flow of $800 \mathrm{ml} / \mathrm{min}$ was selected for this work.

A study was conducted to determine the reaction time necessary for complete formation of the hydrides of arsenic and selenium. The results of this experiment are reported in Figure 6. Examination of this figure reveals a considerable difference in the time necessary for the reactions to go to completion. The absorbance from selenium is seen to increase rapidly and reach a maximum about 45 seconds after addition of the borohydride. Arsine $\left(\mathrm{AsH}_{3}\right)$ is seen to form at a much slower rate, as the maximum in the curve is reached in 80 seconds. $A$

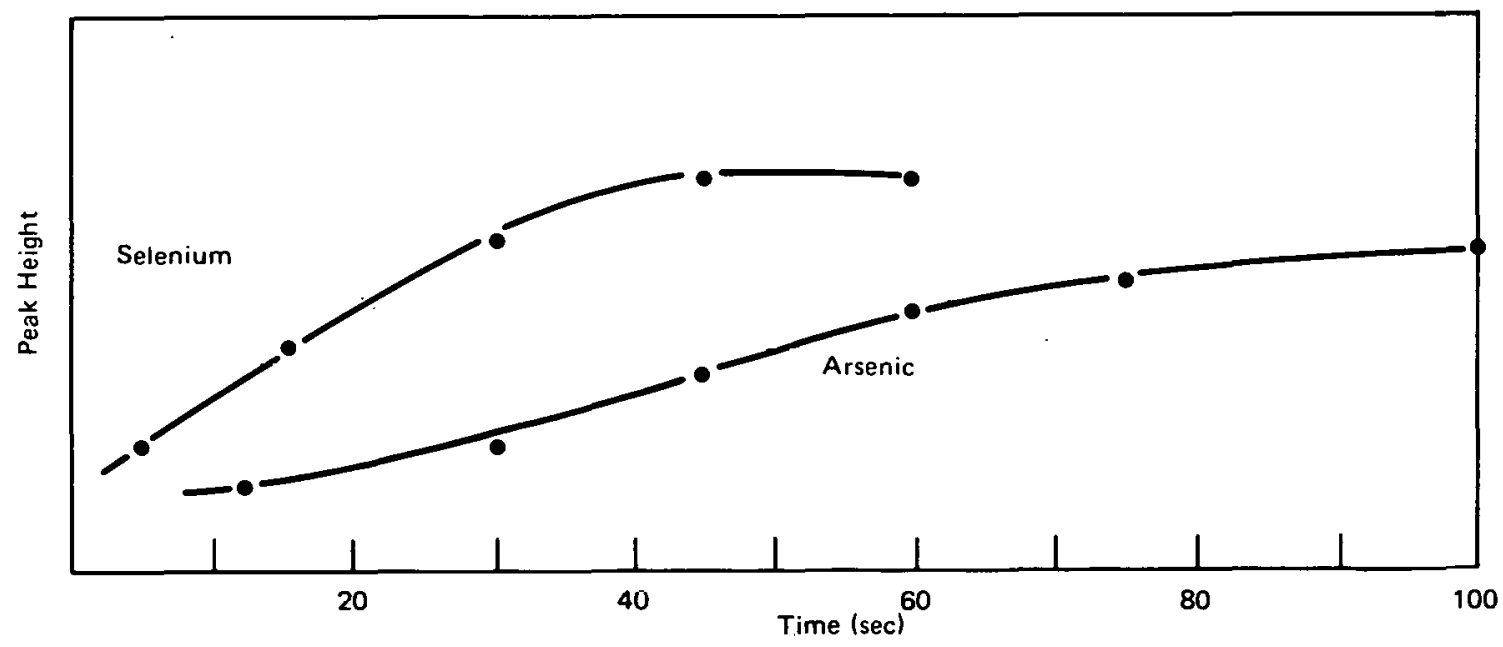

Figure 6. REACTION TIME NECESSARY FOR THE FORMATION OF THE HYDRIDES OF ARSENIC AND SELENIUM. 
reaction time of 45 seconds was chosen for this instrument-the point at which the production of hydrogen selenide $\left(\mathrm{H}_{2} \mathrm{Se}\right)$ is complete. Although the generation of arsine is only $60 \%$ complete at this time, sufficient sensitivity and good reproducibility were achieved. Waiting an additional 35 seconds for the arsine reaction to reach completion would increase the total sample analysis. time by $36 \%$.

\section{Analysis of the Standard Solutions}

A recorder tracing of the simulatneously recorded absorption peaks from arsenic and selenium standards from 0.5 to $16 \mu \mathrm{g} / \mathrm{l}(\mathrm{ppb})$ is given in Figure 7. The blank absorption is

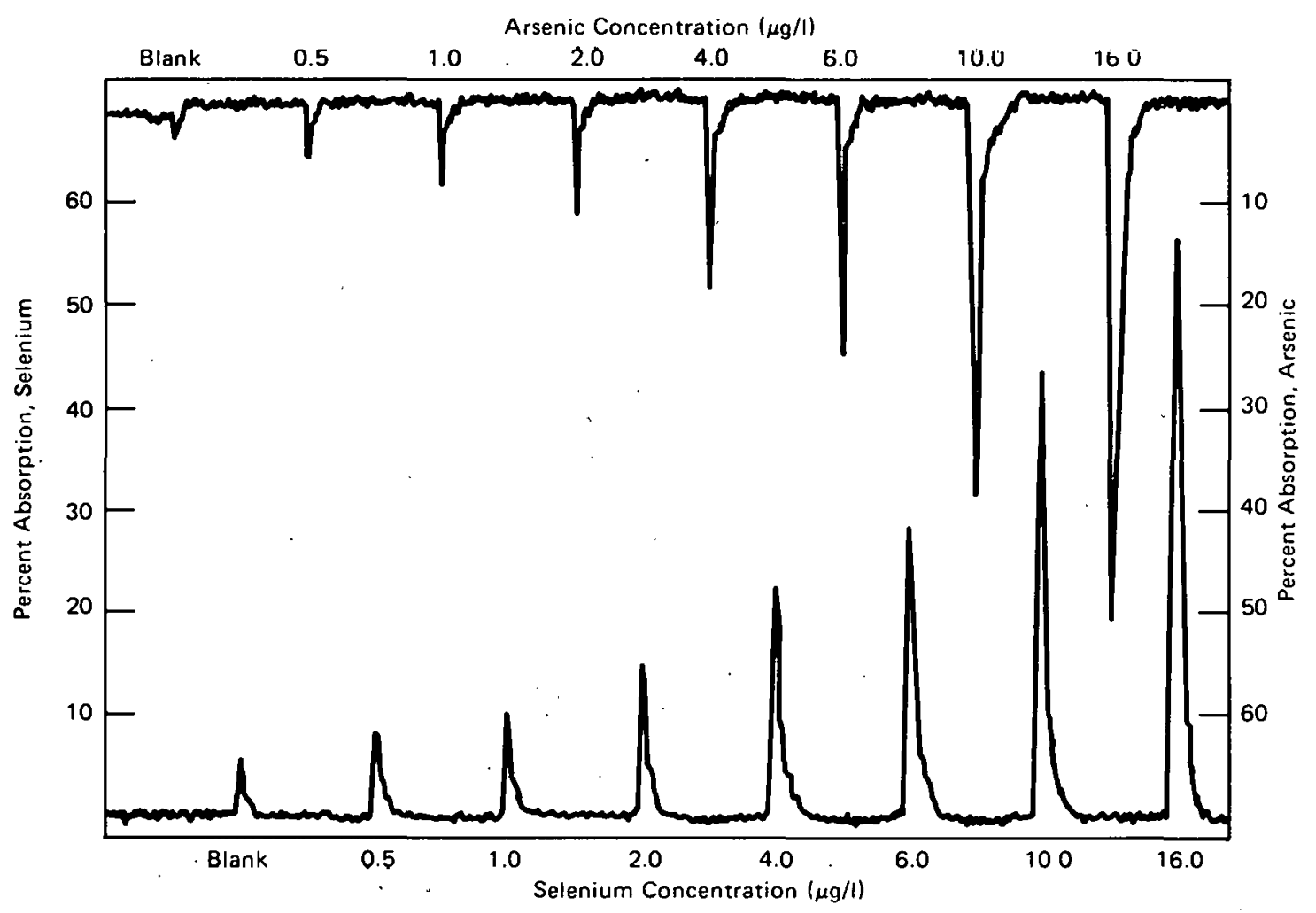

Figure 7. SIMULTANEOUSLY RECORDED ABSORPTION PEAKS FOR ARSENIC AND SELENIUM.

an indication of the finite concentrations of these elements in the reagents. When percent absorption is plotted as a function of the concentration, the resulting curves are linear to $10 \mu \mathrm{g} / \mathrm{l}$ for both elements. Quantitation of samples is by performing a second-order least-squares fit to the peak heights of the standards and using the resulting coefficients to compute the sample concentrations.

The sensitivities and detection limits for arsenic and selenium are listed in Table 1. Sensitivity for the elements was computed from the slope of the plot of percent absorption as a function of concentration. Detection limit is defined as the concentration of the element necessary to yield an absorption signal twice the standard deviation of the noise (background). These values correspond favorably with other reported work, using automated and manually operated instruments. 
The day-to-day precision and accuracy of the automated atomic absorption spectrophotometer are reported in Table 2. These data were taken from standard solutions inserted and analyzed as samples. The precision of the selenium analysis is seen to be significantly better than for arsenic. For both elements, the precision is a usable $20 \%$ at $1 \mu \mathrm{g} / \mathrm{l}(\mathrm{ppb})$.

Table 2

Table 1

SENSITIVITY AND DETECTION LIMIT FOR ARSENIC AND SELENIUM

\begin{tabular}{lcc}
\hline Element & $\begin{array}{c}\text { Sensitivity } \\
(\mu \mathrm{g} / \mathrm{/} / \% \mathrm{~A})\end{array}$ & $\begin{array}{c}\text { Detection Limit } \\
(\mu \mathrm{g} / \mathrm{l})\end{array}$ \\
\hline Arsenic & 0.26 & 0.11 \\
Selenium & 0.18 & 0.05 \\
\hline
\end{tabular}

\begin{tabular}{lccllc}
\hline & \multicolumn{5}{c}{ Sample } \\
\cline { 2 - 6 } & \multicolumn{1}{c}{1} & \multicolumn{1}{c}{2} & \multicolumn{1}{c}{3} & \multicolumn{1}{c}{4} & 5 \\
\hline Standard ( $\mu \mathrm{g} / \mathrm{l})$ & 1.0 & 2.0 & 4.0 & 6.0 & 10.0 \\
Arsenic, Mean $(\mu \mathrm{g} / \mathrm{l})$ & 0.97 & 1.99 & 3.92 & 6.13 & 9.5 \\
Arsenic (\% RSD) & 19 & 11 & 9 & 5 & 6 \\
Selenium, Mean ( $\mu \mathrm{g} / \mathrm{ll})$ & 1.04 & 2.16 & 4.40 & 6.30 & 10.7 \\
Selenium (\% RSD) & 17 & 5 & 5 & 7 & 4 \\
\hline
\end{tabular}

\section{Analysis of the Natural-Water Samples}

An experiment was conducted to determine the day-to-day precision of the analysis of natural water samples for arsenic. Results of this experiment are summarized in Table 3. This series of samples was analyzed over a two-month period in a manner anonymous to the analyst. The calculated precisions for the natural samples agree well with the results in Table 2 for synthetic standards. These results also show a good stability for parts-per-billion concentration of arsenic in natural water.

Three natural-water samples were spiked with $\mu \mathrm{g} / \mathrm{l}$ quantities of arsenic and selenium and the percent recovery computed, using standards prepared in demineralized water. The recoveries are listed in Table 4 and are seen to be nearly quantitative.

Table 3

PRECISION OF ARSENIC ANALYSIS IN NATURAL WATER SAMPLES

\begin{tabular}{llcc}
\hline \multirow{2}{*}{$\begin{array}{c}\text { Analysis } \\
\text { Day }\end{array}$} & \multicolumn{3}{c}{ Samples $(\mu \mathrm{g}$ As/I) } \\
\cline { 2 - 4 } 1 & \multicolumn{1}{c}{1} & \multicolumn{1}{c}{2} & 3 \\
\hline 1 & 4.2 & 2.3 & 1.4 \\
4 & 3.7 & - & 1.2 \\
17 & 3.4 & 1.5 & - \\
29 & 3.4 & 2.1 & 1.1 \\
50 & 4.1 & 2.3 & 1.7 \\
58 & 3.9 & & 1.6 \\
Mean & 3.8 & 2.1 & 1.4 \\
S & 0.34 & 0.38 & 0.25 \\
$\%$ RSD & 9 & 18 & 18 \\
\hline
\end{tabular}

Table 4

RECOVERY OF ARSENIC AND SELENIUM ADDED TO NATURAL WATER SAMPLES

\begin{tabular}{ccccc}
\hline $\begin{array}{c}\text { Sample } \\
\text { Number }\end{array}$ & $\begin{array}{c}\text { Present } \\
(\mu \mathrm{g} / 1)\end{array}$ & $\begin{array}{c}\text { Added } \\
(\mu \mathrm{g} / 1)\end{array}$ & $\begin{array}{c}\text { Found } \\
(\mu \mathrm{g} / 1)\end{array}$ & $\begin{array}{c}\text { Percent } \\
\text { Recovery }\end{array}$ \\
\hline \multirow{3}{*}{$\begin{array}{c}\text { Arsenic } \\
1\end{array}$} & 1.9 & 1.0 & & \\
\cline { 3 - 5 } 2 & 1.1 & 2.0 & 3.0 & 110 \\
3 & 2.2 & 4.0 & 6.1 & 105 \\
& & Selenium & & 98 \\
1 & $<0.2$ & 6.8 & 6.5 & 96 \\
2 & $<0.2$ & 6.8 & 6.8 & 100 \\
3 & $<0.2$ & 6.8 & 6.7 & 99 \\
\hline
\end{tabular}




\section{REFERENCES}

1. Fernandez, F. S.; Atomic Absorption News/etter, 12, (4), p 93 (1973).

2. King, H. G. and Morrow, R. W.; Determination of Arsenic and Selenium in Surface Water by Atomic Absorption to Support Environmental Monitoring Programs, Y-1956; Union Carbide Corporation-Nuclear Division, Oak Ridge Y-12 Plant, Oak Ridge, Tennessee (1974).

3. Pollock, E. N. and West, S. J.; Atomic Absorption Newsletter, 12, (1), p 6 (1973).

4. Schmidt, F. J. and Royer, J. L.; Anal Lett, 6, p 17 (1973).

5. Goulden, P. D. and Brooksbank, P. B.; Anal Chem, 46, (11), p 1431 (1974).

6. Kan, K. T.; Anal Lett, 6, (7), p 603 (1973).

7. Friorino, J. A., Jones, J. W., and Capor, S. G.; Anal Chem, 48, (1), p 120 (1976). 


\section{Distribution}

Bendix Field Engineering - Grand Junction

Barton, T. H.

Livingston, $D$.

Department of Energy - Grand Junction

Boyer, B.

Dahlem, D. H.

Grutt, E. W.. Jr

Roach, C. H.

Shannon, S.

Department of Energy - Oak Ridge

Hickman, H. D.

Leed, R. E.

Zachry, D. S., Jr

\section{Lawrence Livermore Laboratory}

TInney, J. F.

Los Alamos Scientific Laboratory

Sharp, R. R.

Oak Ridge Gaseous Diffusion Plant

Arendt, J. W.

Cagle, G.W.

Carpenter, L. J.

Farrar, R. B.

K.wosnoski, T.

Levin, R. W.

Nichols, C. E.

Stewart, J. H., Jr

Stief, S. S.

Wilcox, W. J., Jr

Bernander, N. K.

Briscoe, O.W.

Burditt, R. B.

Dodson, W. H./Googin, J. M.

Duggan, H. G.

Foulk, D. L.

Fraser, R. J.

Futrell, T. L. (5)

Hamilton, J. H.

Hopwood, W. H.

Jackson, V. C.

Jones, F. W.

Kahl, K. G.

Keith, A.

Kite, H. T:

Larson, G. F.

Mason, D. L./Schreyer, J. M.

McBryde, W. T.

McLendon, J. D:

Mills, J. M., Jr

Morrow, M. K.

Morrow, R. W. (10)

Oliphant, G. W.

Phillips, L. R.

Smith, R. D.

Stoner, H. H.

Tewes, W. E.

White. J. C.

White, L. E.

Whitson, W. K.

$Y-12$ Central Files (master copy)

Y-12 Central Files (route copy)

$Y$-12 Central Files (Y-12RC)

$Y-12$ Central Files (5)

Oak Ridge National Laboratory

Laing, W. R.

Paducah Gaseous Diffusion Plant

Rickard, R. R.

Bewley, H. D.

Simmons, R. L.

Oak Ridge Y.12 Plant

Savannah River Laboratory

Adams, T. T. (5)

Folger, R. L.

Alvey, H. E.

Andrew, R. E.

In addition, this report is distributed in accordance with the category UC-51, Nuclear Raw Materials, as given in the USERDA Standard Distribution Lists for Unclassified Scientific and Technical Reports, TID-4500. 